\title{
Successful Anesthetic Management of a Kyphoscoliotic Hurler Syndrome Patient with Sugammadex in Ventriculoperitoneal Shunt Surgery
}

\author{
Ventrikuloperitoneal Șant Yerleștirilen Kifoskolyotik Hurler Vakasında Sugammadeks ile Bașarılı \\ Anestezi Yönetimi
}

\author{
Ahmet Șen'1, Bülent Özdemir², Bașar Erdivanlı1', Vaner Köksal² \\ ${ }^{1}$ Department of Anesthesiology and Reanimation, Recep Tayyip Erdoğan University, Rize, Turkey; ${ }^{2}$ Department of Neurosurgery, Recep \\ Tayyip Erdoğan University, Rize, Turkey
}

\begin{abstract}
Hurler Syndrome is a rare autosomal recessive disorder associated with progressive mental retardation and glycosamine deposition in several organs. We present a kyphoscoliotic patient with Hurler syndrome scheduled for ventriculoperitoneal shunt placement and discuss the anesthetic management.

The patient presented with many features complicationg all phases of anesthesia such as kyphoscoliosis, restrictive and obstructive pulmonary disease. Several problems such as hypercarbia and secretions necessitated sugammadex for reversal of neuromuscular blockade. The patients presenting with congenital metabolic syndromes are difficult to manage, either by general anesthesia or regional anesthesia. With increased lifespans, they more frequently undergo surgeries requiring general anesthesia. We are in opinion that sugammadex provides prompt recovery of muscular function without increasing secretions, and safer anesthesia.
\end{abstract}

Key words: Hurler syndrome; kyphoscoliozis; restrictive lung disease; obstructive lung disease; anesthetic complications; sugammadex

\section{ÖZET}

Hurler Sendromu pek çok organda glikozamin depolanması ve ilerleyici mental bozuklukla karakterize, seyrek görülen bir otozomal resesif hastalıktır. Ventriküloperitoneal șant ameliyatı planlanan, kifoskolyotik Hurler hastasını ve anestezi yönetimini sunmaya çalıștık.

Hasta, kifoskolyoz, restriktif ve obstruktif akciğer hastalığı gibi, anestezinin her așamasını zorlaștıran pek çok özelliğe sahipti. Hiperkarbi ve sekresyonlar, nöromusküler bloğun geri döndürülme-sinde sugammadeks kullanımını zorunlu hale getirdi. Konjenital metabolik sendromlara sahip hastaların, hem genel

Yard. Doç. Dr. Başar Erdivanl, İslampaşa Mahallesi, Sehitler Caddesi, Rize, Türkiye, Tel.04642130491Email.berdivanli@gmail.com

Geliş Taribi: 12.10.2014 • Kabul Taribi: 18.10.2016 hem de rejyonel anestezi açısından takibi zordur. Yașam süreleri arttıkça, genel anestezi gerektiren ameliyatlara daha sık ihtiyaç duymaktadırlar. Sugammadeks ile, bu tür hastalarda sekresyonlar artmaksızın musküler fonksiyonun hızlıca geri döndüğü ve daha güvenli anestezi sağlandığı kanaatindeyiz.

Anahtar kelimeler: Hurler sendromu; kifoskolyoz; restriktif akciğer hastalı̆ı; obstruktif akciğer hastalığı; anestezi komplikasyonları; sugammadeks

\section{Introduction}

Hurler Syndrome is a rare autosomal recessive disorder (however the most commonly encountered mucopolysaccharidosis syndrome) associated with progressive mental retardation and glycosamine deposition in several organs due to deficiency of alpha-L iduronidase ${ }^{1}$. Distinct facial features become prominent in the second year of life. Anesthetic management becomes more difficult as several organs enlarge due to glycosamine deposition: the facial deformities complicate mask ventilation and intubation, airway disease and cardiac insufficiency as early as age of ten increases perioperative morbidity ${ }^{2}$. We present a kyphoscoliotic patient with Hurler syndrome scheduled for ventriculoperitoneal shunt placement and accompanying difficulties.

\section{Case Presentation}

Nine-years-old (height: $133 \mathrm{~cm}$, weight: $27 \mathrm{~kg}$ ) white female with Hurler syndrome, previously operated for ventriculoperitoneal shunt placement, presented with severe headache. Cranial CT showed wide ventricles with periventricular oozing (Figure 1). The shunt was not functional, however could be manually pumped. 

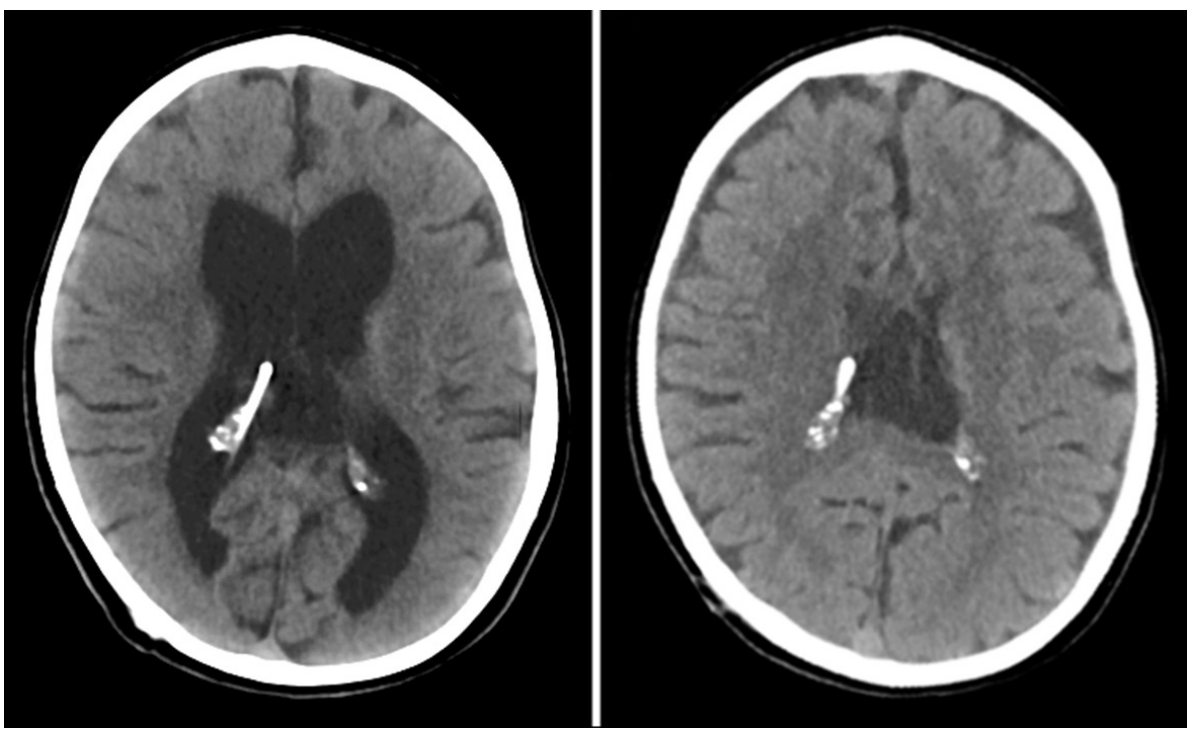

Figure 1. a, b. Preoperative axial computerized tomography scan of the brain shows the ventricular dilatation (a), and resolution of the dilatation after manually operating the dysfunctional shunt (b).

The patient was scheduled for ventriculoperitoneal shunt placement due to communicating hydrocephalus. Her medical history included chronic otitis media, frequent infections of the tooth, tonsils and lower airways, congenital mitral valve prolapsus, obstructive sleep apnea, and restrictive airway disease due to kyphoscoliosis. Laboratory values were normal except for high antistreptolysin $\mathrm{O}$ titre (270 IU, ref range $<200$ ), and thyroid hormone levels (free T4: $1.5 \mathrm{ng} / \mathrm{dl}$, ref range: $0.7-1.48$, free $\mathrm{T} 3: 4.6 \mathrm{pg} / \mathrm{ml}$, ref range: 1.7 3.7, TSH was normal). Physical examination revealed a coarse face and flat nasal bridge, large tongue and tonsils, hypoplastic mandible, a short and rigid neck complicating the extension of the head, corneal degeneration, multiple musculoskeletal anomalies including kyphoscoliosis, and hepatosplenomegaly (Figure 2). The mallampati score was III, vital signs were comparable to age specific references.

We premedicated the patient with iv atropine 0.02 $\mathrm{mg} / \mathrm{kg}$, prednisolone $1 \mathrm{mg} / \mathrm{kg}$, ranitidine $2 \mathrm{mg} / \mathrm{kg}$, and metoclopramide $0.1 \mathrm{mg} / \mathrm{kg}, 30 \mathrm{~min}$ before the surgery. We included fast track LMA, videolaryngoscope, and fiberoptic bronchoscope in addition to other airway devices. We induced anesthesia with iv midazolam $0.01 \mathrm{mg} / \mathrm{kg}$, fentanyl $2 \mathrm{mcg} / \mathrm{kg}$, propofol $2.5 \mathrm{mg} / \mathrm{kg}$ and administered iv rocuronium 1.2 $\mathrm{mg} / \mathrm{kg}$ after observing adequate mask ventilation. During laryngoscopy, Cormack-Lehane score was 3, the tonsils and the large tongue left a narrow space for manipulation and extension should be avoided to prevent atlantoaxial sublaxation, but we experienced no difficulty in intubation using a stylus in a 5.0 portex tube. We maintained anesthesia with

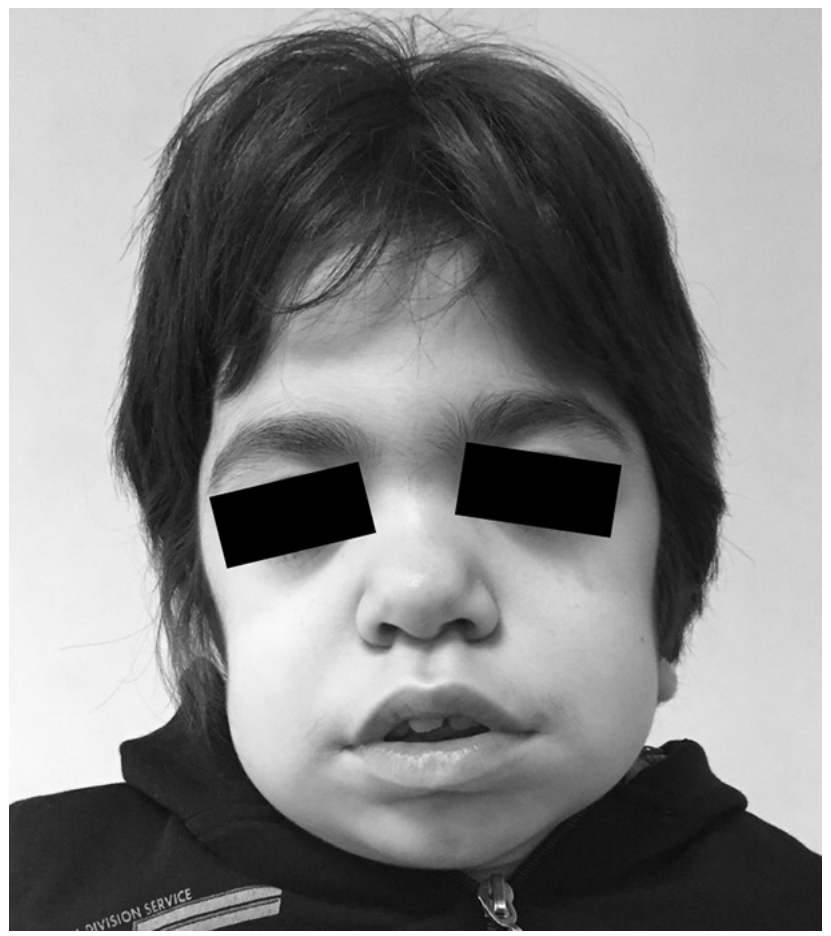

Figure 2. The photograph shows the coarse face, flat nasal bridge, hypoplastic mandible, and the short neck of the patient. 

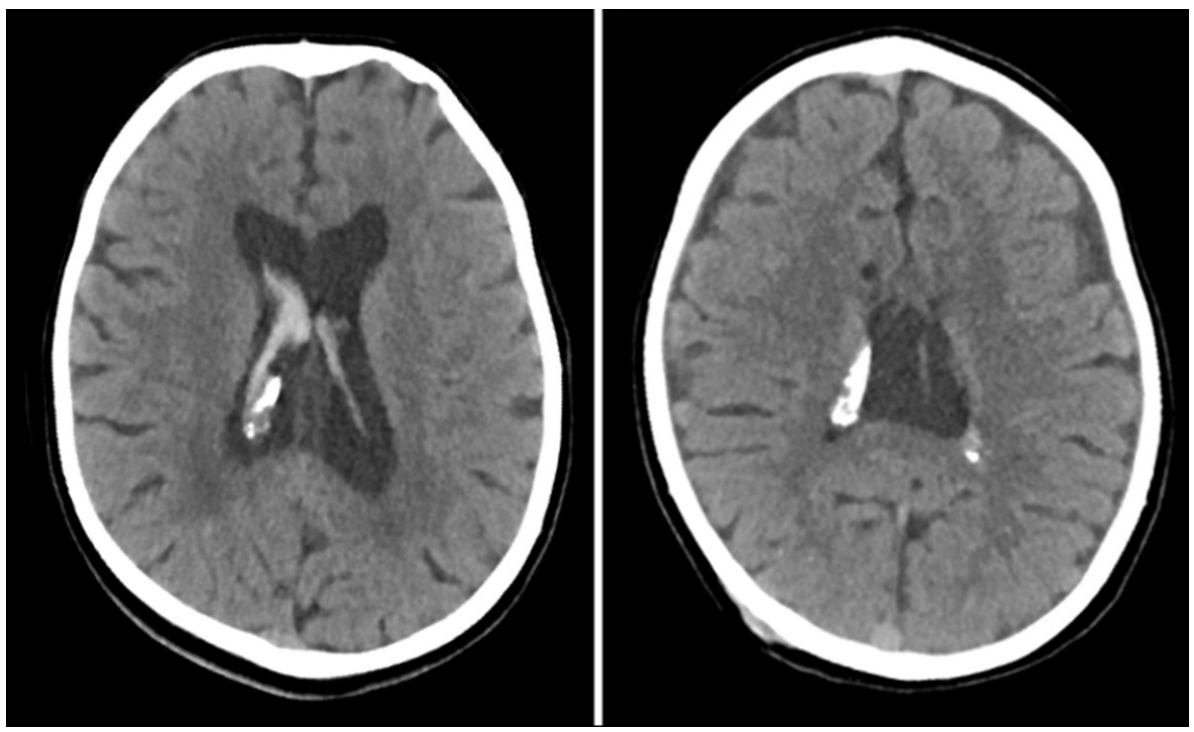

Figure 3. a, b. Postoperative axial computerized tomography scan of the brain shows the decrease in the ventricular dilatation at the first postoperative day (a), and two months later (b).

$40-60 \% \mathrm{O}_{2}-\mathrm{N}_{2} \mathrm{O}$, and $1.5 \%$ sevoflurane. Ventilation was difficult as the peak airway pressure exceeded 30 $\mathrm{cmH}_{2} \mathrm{O}$ and rhonchis were present. We continuously aspirated clear secretions from both lungs via fiberoptic bronchoscopy to eliminate atelectasis. Although the patient was well ventilated (VTE: $270 \mathrm{ml}, \mathrm{f}: 16$ $\mathrm{min}^{-1}$, PIP: $20 \mathrm{cmH}_{2} \mathrm{O}$ ), the $\mathrm{SpO}_{2}$ was around $92 \%$ and the $\mathrm{EtCO}_{2}$ was around $45 \mathrm{mmHg}$ throughout the surgery, which lasted for 35 minutes. Therefore, at the end of the surgery, we increased $\mathrm{FiO}_{2}$ to $50 \%$ and reversed the neuromuscular blockage with $2 \mathrm{mg} / \mathrm{kg}$ sugammadex instead of neostigmine. Postoperative cranial CT showed air in frontal and occipitial lobes, increased density in periventricular white matter and $7.5 \mathrm{~mm}$ wide calcification in pineal region (Figure 3). The patient was reliefed of headache and discharged at the ninth postoperative day.

\section{Discussion}

Our main concern was the intubation. Signs like large tongue and tonsils, high Mallampati score, hypoplastic mandible, short and rigid neck were alarming and we prepared the flexible fiberoptic bronchoscope and the laryngeal mask airway as rescue tools ${ }^{3,4}$. Awake intubation with the fiberoptic bronchoscope was a good option. However, we anticipated the need for adequate muscle relaxation, since the patient had signs of increased intracranial pressure. Deep sedation was an alternative to muscle relaxation, but since we had access to sugammadex, we preferred to rapidly induce a deep neuromuscular block with highdose rocuronium instead. This technique provided an uncomplicated intubation. Despite atropine pretreatment, we observed increased secretions following intubation. Preoperatively we discussed about premedicating the child with a histamine blocker and decided to go without it, since antihistaminics dry secretions and make them more copious. We think that this is the right choice, because copious secretions could be very hard to aspirate in this child with kyphoscoliosis. We may argue that we applied a lower atropine dose than that required in this patient. After atropine premedication, the heart rate increased to $120 / \mathrm{min}$, therefore in our opinion, there was no margin left for extra atropine dose.

Extubation could be complicated by hypoxia due to secretions and by pulmonary edema due to laryngospasm or inadequate recovery ${ }^{5}$. This patient had both restrictive and obstructive pulmonary disease, and the deep neuromuscular block should be reversed adequately. Therefore, we administered the recommended dose of sugammadex to obtain prompt recovery of the neuromuscular function ${ }^{6}$. Sugammadex does not cause increase in bronchial secretions, which was very important in a patient with copious secretions. Sugammadex also has a very low incidence of residual neuromuscular blockade, again, an important factor of postoperative respiratory complications. Since we 
were able to use less intravenous and inhalational anesthetics, we observed no residual sedation after the extubation phase.

Anesthetic management is difficult in patients with congenital metabolic syndromes. The anesthesiologists should expect and be prepared to administer general anesthesia to more of these patients due to their increasing lifespans. Sugammadex, as part of a careful perioperative plan, may provide safer general anesthesia in these patients.

\section{Financial Disclosure}

The authors have no financial interests related to the material in the manuscript.

\section{References}

1. Frawley G, Fuenzalida D, Donath $S$, et al. A retrospective audit of anesthetic techniques and complications in children with mucopolysaccharidoses. Paediatr Anaesth 2012;22(8):737-44.

2. Walker RW, Darowski M, Morris P, et al. Anaesthesia and mucopolysaccharidoses. A review of airway problems in children. Anaesthesia 1994;49(12):1078-84.

3. Khan FA, Khan FH. Use of the laryngeal mask airway in mucopolysaccharidoses. Paediatr Anaesth 2002;12(5):468.

4. Walker RW, Allen DL, Rothera MR. A fibreoptic intubation technique for children with mucopolysaccharidoses using the laryngeal mask airway. Paediatr Anaesth 1997;7(5):421-6.

5. Walker RW, Colovic V, Robinson DN, et al. Postobstructive pulmonary oedema during anaesthesia in children with mucopolysaccharidoses. Paediatr Anaesth 2003;13(5):441-7.

6. Gaszynski T, Szewczyk T, Gaszynski W. Randomized comparison of sugammadex and neostigmine for reversal of rocuroniuminduced muscle relaxation in morbidly obese undergoing general anaesthesia. Br J Anaesth 2012;108(2):236-9. 